\title{
Antimicrobial Screening of Euphorbia hirta L. and Pedalium murex L. - A Comparative Study \\ S.Jenifer
}

Assistant Professor in Department of Biotechnology, Bon Secours College, Thanjavur, Tamilnadu, India

\section{ABSTRACT}

Medicinal plants have been used for centuries as remedies for human diseases because they contain components of therapeutic value. Herbal medicine is still mainstay of about $75-80 \%$ of the whole population, mainly in developing countries, for primary health care because of better cultural acceptability, better compatiability with the human body and fewer side effects. Euphorbia hirta (amman pacharisi) is a small perennial herb which belongs to the family of Euphorbiaceae and it is used to treat bronchitic asthma, ameoboidal dysentry and laryngeal spasm. Pedalium murex (yanai nerunjil) is a much-branched annual herb. This belongs to the family of Pedaliaceae and is used to treat gonohorrea, urinary track infections and spermatohorrea.The present study is to compare the antibacterial and antifungal activity of aqueous and organic solvent leaf extracts of Euphorbia hirta and Pedalium murexThe antimicrobial assay is done by disc diffusion method []against bacterial species (Pseudomonas putida, Pseudomonas aeruginosa, Klebsiella pneumoniae, Aeromonas liquefaciens and Icaligenes spp.) and fungal species (Aspergillus niger, Aspergillus flavus, Aspergillus fumigatus, Aspergillus erythrocephalus and Fusarium spp.).

\section{Council for Innovative Research}

Peer Review Research Publishing System

Journal of Advances in Natural Sciences

Vol. 3, No. 1

editorjansonline@gmail.com

www.cirworld.com 


\section{Introduction}

Euphorbia hirta is a pantropical weed, possibly native to India. It is a hairy herb that grows in open grasslands, roadsides and pathways. It is widely used as a medicinal herb in most places it grows. In the test tube, Euphorbia hirta has been shown to kill various types of pathogenic bacteria, Plasmodium (potently) Euphorbia hirta has been claimed to have a curative effects on dengue patients, based on personal testimonies, particularly in the Philippines. Despite its widespread use, there is no evidence to support this claim (Srinivas et al, 2011, Yoganarasimhan S.N. 2000) Pedalium is a genus of plant in the Pedaliacae family comprising one species, Pedalium murex. It is distributed in India, Sri Lanka and Tropical Africa. Pedalium Murex is a fruit-bearing herb that has its history intertwined with Tribulus terrestris due to the visual similarities of the two fruits and their traditional interchanging in Goshukra formulas. Pedalium fruits are much less studied than Tribulus fruits currently.Preliminary evidence suggests that Pedalium could increase testosterone and act as an aphrodisiac, although there are no human studies currently. (Sankara Subramanian 1972, Yogendra et al 1983) The exact bioactives in Pedalium are equally unknown, and all that can be said is that many of the bioactivities of Pedalium are somewhat similar to Tribulus. (Katewa ss et al 2005. Balakrishnan V et al 2009. Dipali and Das 1995. Singh et al 2010.)

\section{MATERIALS AND METHODS}

\section{Collection of Plant Materials:}

The fresh and disease free plant leaves were collected from fallow land and wayside thorny shrubs, of Thanjavur, Tamilnadu, India and taken to laboratory. The herbarium specimens of these plants were deposited in medicinal plants herbarium, Trichy.

\section{Microorganism:}

The human pathogenic bacterial species [Pseudomonas putida, Pseudomonas aeruginosa, Klebsiella pneumoniae, Alcaligenes spp. and Aeromonas liquefaciens] and fungal species [Aspergillus niger, Aspergillus flavus, Aspergillus erythrochephalus, Aspergillus fumigatus and Fusarium spp.] were collected from the Microbial Culture Collection Unit (MCCU), Herbarium Reseach Unit,trichy,Tamil Nadu.

\section{Preparation of Plant Extracts}

The leaves of both plants [Euphorbia hirta and Pedalium murex] were surface sterilized with running tap water (3 times) and soaked in $0.1 \%$ mercuric chloride solution. Finally, the leaves were washed with distilled water and shade dried.

About $1 \mathrm{~g}$ of leaves were grounded in mortar and pestle with $10 \mathrm{ml}$ of aqueous and organic solvents [acetone, chloroform, benzene, butanol, ethanol, dimethylformamide and diethyl ether] and centrifuged at 10,000rpm for 15 minutes. The supernatant was obtained and used for in vitro antimicrobial screening.

\section{Antimicrobial Assay}

The antimicrobial activity of the plant extracts were tested using disc diffusion method (Bauer et at 1966. Thornsberry et al 1988.)

\section{Testing of Antibacterial activity}

The sterilized Nutrient Agar medium (10ml) was poured into each sterile petriplate and allowed to solidify. The sterile cotton swab was dipped into the young bacterial cultures (20 hours) and swabbed over the entire agar surface on each petriplate. The sterile discs ( $5 \mathrm{~mm}$ diameter) were loaded with $10 \mu \mathrm{l}$ of each plant extract and kept undisturbed for the evaporation of solvents. Then, the discs were placed on the center of the petriplates and incubated at $37^{\circ} \mathrm{C}$ for $24 \mathrm{hours}$. The antibacterial activity was recorded by measuring the diameter of inhibition zone around each disc (in $\mathrm{mm}$ ).

\section{Testing of antifungal activity}

The above same procedure was repeated for testing antifungal activity. Instead of Nutrient agar medium, Potato Dextrose agar medium was poured into the sterile petriplates and then swabbed with young fungal cultures. Then, the discs (5mm diameter) with plant extracts were placed on the center for 3 days. The diameter of the inhibition zone was measured and its show antifungal activity.Acetone and butanol extracts of both the plants showed moderate activity. The other organic solvent extracts of both the plants showed moderate to least activity. Diethyl ether extracts of both plants was inactive against tested bacterial strains. The aqueous extract showed moderate activity in Pedalium murex, while Euphorbia hirta had least activity against single organism (Pseudomonas aeruginosa) and others are found to be inactive

\section{RESULTS AND DISCUSSION}

Efficacy of Euphorbia hirta and Pedalium murex against pathogenic bacterial strains: The results of the in vitro assays of antibacterial activity of selected medicinal plant extracts against bacterial strains (Table-1\&2) Among the organism tested, Pseudomonas putida was strongly inhibited by both the plants. The other organisms reflect moderate activity.Among the different solvent used, ethanolic extract (Euphorbia hirta) and dimethyl formamide extract (Pedalium murex) contributed excellent activity against all the tested bacterial pathogens. Acetone and butanol extracts of both the plants showed moderate activity. The other organic solvent extracts of both the plants showed moderate to least activity. Diethyl ether extracts of both plants was inactive against tested bacterial strains. The aqueous extract showed 
moderate activity in Pedalium murex, while Euphorbia hirta had least activity against single organism (Pseudomonas aeruginosa) and others are found to be inactive. Efficacy of Euphorbia hirta and Pedalium murex against pathogenic fungal strains:The results of the in vitro assay of antifungal activity against the tested fungal pathogens (Table-3\&4). Among the five organisms tested, Fusarium spp., was inhibited by both the plant extracts. The other organisms showed moderate to least activity. Aspergillus niger cannot be inhibited by both the plant extracts. Among the solvents used, butanol and ethanol extracts (Pedalium murex) showed some activity, while dimethyl formamide and benzene extracts (Euphorbia hirta) contributed excellent activity against all tested fungal pathogens. The other solvent extracts of both the plants showed moderate to least activity. The chloroform, diethyl ether and aqueous extracts of both the plants had no activity against all the tested fungal strains.

\section{SUMMARY AND CONCLUSION}

The Euphorbia hirta extracts had better antifungal activity, but moderate antibacterial activity while, the Pedalium murex extracts expressed significant antibacterial activity but least antifungal activity. From our screening experiments, the results showed that the most active constituents present in these plants can be subjected to isolation of the therapeutic antimicrobials and undergo further pharmacological evaluation

\section{REFERENCE:}

1. Yoganarasimhan S.N. Medicinal plants of India, Tamil nadu. Vedam books(p) Itd, new delhi,2000. 446-47p.

2. Srinivas et al. Antioxidant activity of pedalium murex fruits in carbon tetra chloride-Induced Hepatopathy in rat.International Journal of Pharma and Bio Sciences 2011,vol.2/issue.1/p-622

3. Sankara Subramanian S, Nair AGR. Flavonoids of the leaves of $P$. murex. Phytochemistry. 1972;11:464-465.

4. Yogendra N, Shukla Raghunath S, Thakur Hepta triacontan-4-1, tetratriacontanyl octacosanoate and other constituents from P. murex. Phytochemistry. 1983;22(4):973-974.

5. Katewa SS, Galav PK. Traditional herbal medicines from Shekhawati region of Rajasthan. Indian J Tradit Knowl 2005; 4(3): 237-245.[28]

6. Balakrishnan V, Prema P, Ravindran KC, Robinson JP. Ethnobotanical Studies among Villagers from Dharapuram Taluk, Tamil Nadu, India.Global J Pharmacol2009; 3(1): 8-14.[29]

7. Dipali D, Das MN. Pharmacognostical studies of root and fruit of Gokshura (Pedalium murexLinn.). BMEBR 1995; 16(1-2):54- 65.[30]

8. Singh L, Soni P, Vasistha HB, Kamboj SK. Rare and threatened species of medicinal value under Prosopis juliflora(Swartz) DC. in District Tuticorin, Tamil Nadu ( India). New York Sci J2010

9. Bauer AW, Kirby MM, Sherris JC, Truck M. Antibi-otic susceptibility testing by a standardized

10. single disk method. Am J Clin Pathol1966; 45:493-6.

11. Thornsberry C, Sweson JM, Baker CN, Mc DougalLK, Stocker SA, Hill BC. Methods for deter-mining susceptibility of fastidious and unusualpathogens to select antimicrobial agents. DiagMicrobiol Infect Dis1988; 9: 139-53. 
Table: 1- Antibacterial Activity of Leaf Extracts of Euphorbia hirta

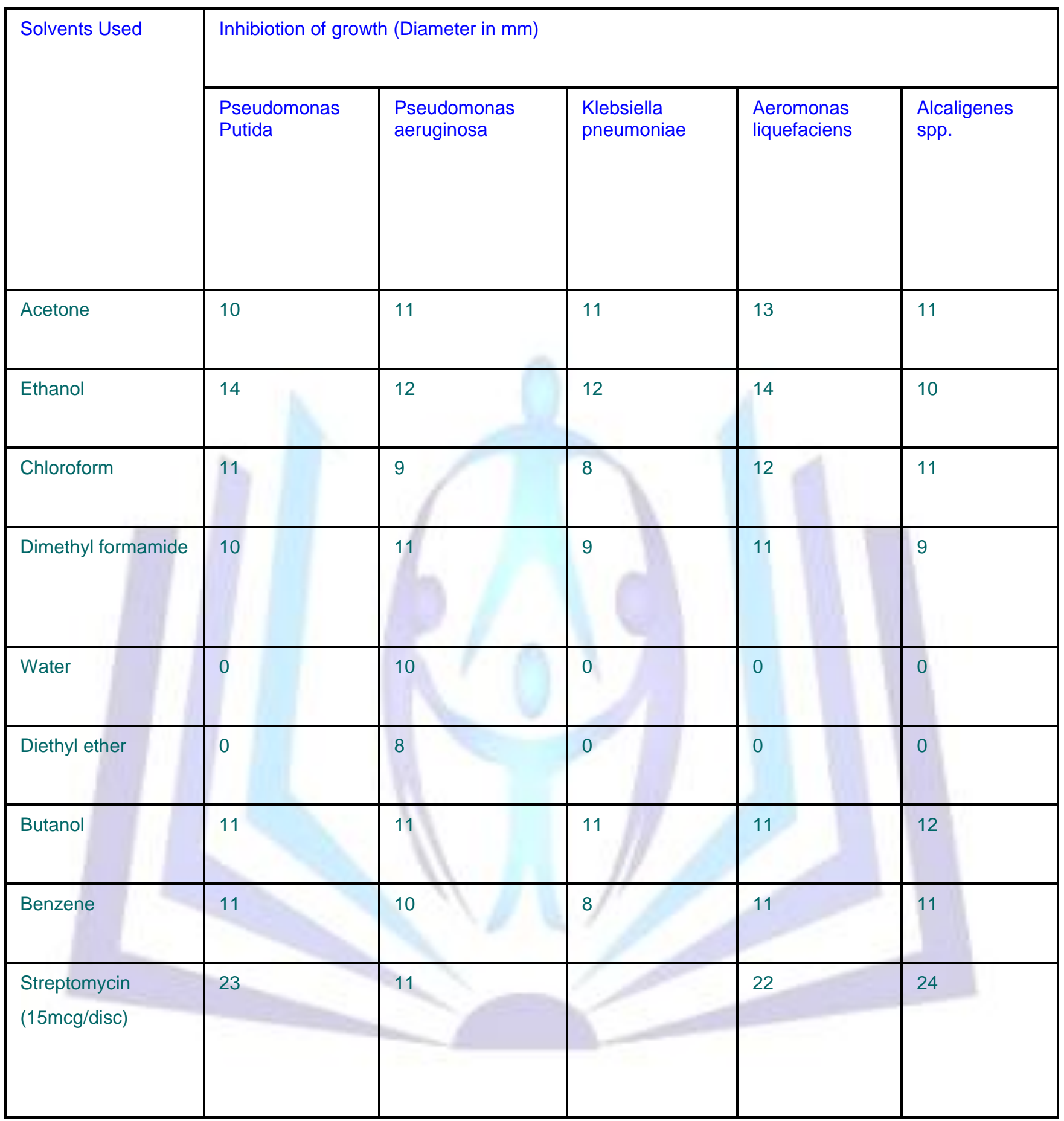


Table: 2 - Antibacterial Activity of Leaf Extracts of Pedalium murex

\begin{tabular}{|c|c|c|c|c|c|}
\hline \multirow[t]{2}{*}{ Solvents Used } & \multicolumn{5}{|c|}{ Inhibition of Growth (Diameter in mm) } \\
\hline & $\begin{array}{l}\text { Pseudomonas } \\
\text { Putida }\end{array}$ & $\begin{array}{l}\text { Pseudomonas } \\
\text { aeruginosa }\end{array}$ & $\begin{array}{l}\text { Klebsiella } \\
\text { pneumoniae }\end{array}$ & $\begin{array}{l}\text { Aeromonas } \\
\text { liquefaciens }\end{array}$ & $\begin{array}{l}\text { Alcaligenes } \\
\text { spp. }\end{array}$ \\
\hline Acetone & 18 & 20 & 10 & 10 & 10 \\
\hline Ethanol & 16 & 15 & 12 & 12 & 12 \\
\hline Chloroform & 9 & 10 & 8 & 10 & 8 \\
\hline $\begin{array}{l}\text { Dimethyl } \\
\text { formamide }\end{array}$ & 18 & 11 & 18 & 11 & 17 \\
\hline Water & 9 & 0 & 9 & 11 & 9 \\
\hline Diethyl ether & 0 & 0 & 10 & 0 & 0 \\
\hline Butanol & 14 & 13 & 12 & 16 & 14 \\
\hline Benzene & 7 & 10 & 0 & 8 & 8 \\
\hline $\begin{array}{l}\text { Streptomycin } \\
\text { (15mcg/disc) }\end{array}$ & 23 & 11 & & 22 & 24 \\
\hline
\end{tabular}


Table: 3 - Antifungal Activity of Leaf Extracts of Euphorbia hirta

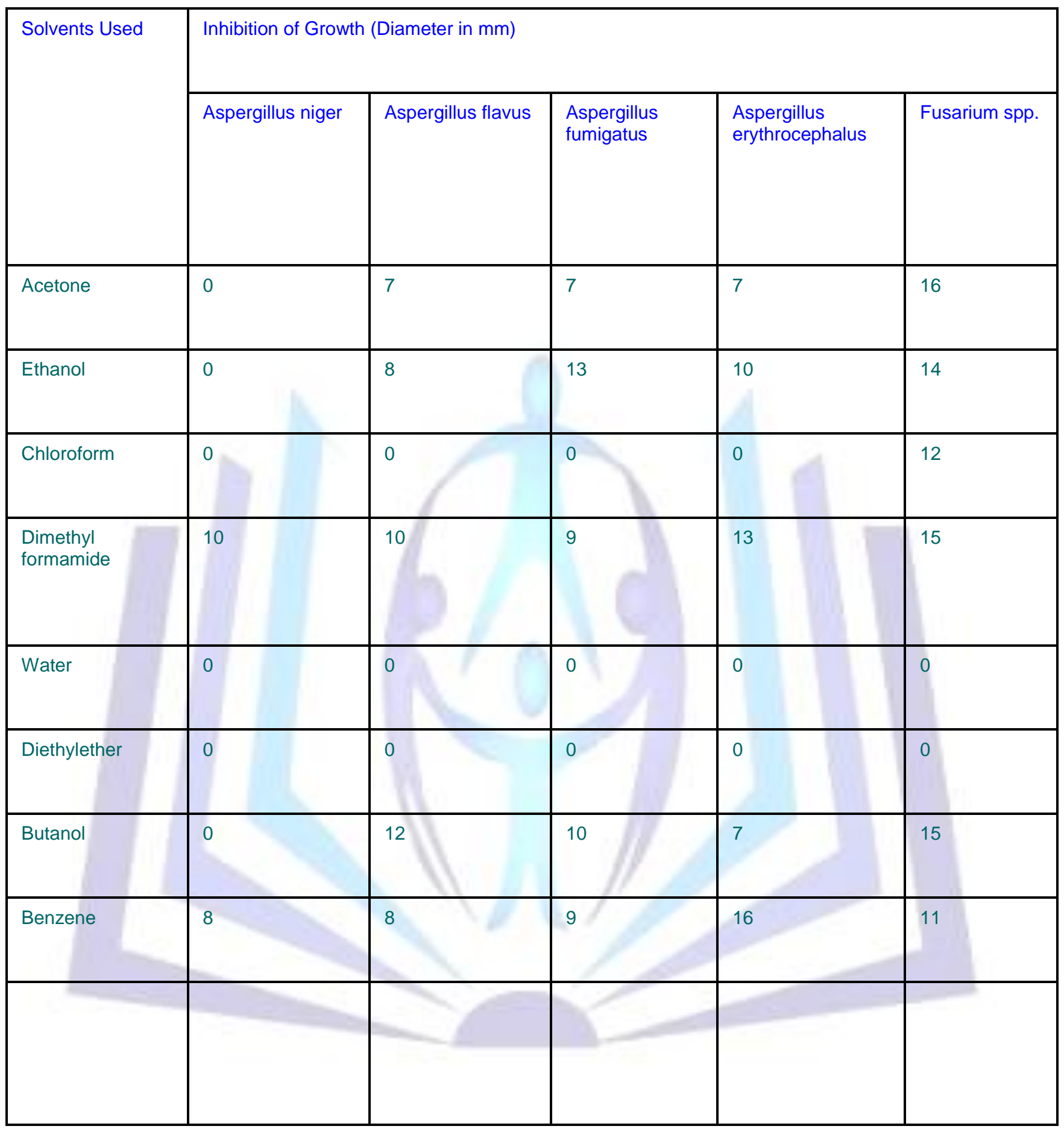


Table: 4 - Antifungal Activity of Leaf Extracts of Pedalium murex

\begin{tabular}{|c|c|c|c|c|c|}
\hline \multirow[t]{2}{*}{ Solvents Used } & \multicolumn{5}{|c|}{ Inhibition of Growth (Diameter in mm) } \\
\hline & Aspergillus niger & Aspergillus flavus & $\begin{array}{l}\text { Aspergillus } \\
\text { fumigatus }\end{array}$ & $\begin{array}{l}\text { Aspergillus } \\
\text { erythrocephalus }\end{array}$ & Fusarium spp. \\
\hline Acetone & 0 & 0 & 0 & 0 & 0 \\
\hline Ethanol & 0 & 12 & 13 & 8 & 8 \\
\hline Chloroform & 0 & 0 & 0 & 0 & 0 \\
\hline $\begin{array}{l}\text { Dimethyl } \\
\text { formamide }\end{array}$ & 0 & 0 & 8 & 0 & 11 \\
\hline Water & 0 & 0 & 0 & 0 & 0 \\
\hline Diethyl ether & 0 & 0 & 0 & 0 & 0 \\
\hline Butanol & 8 & 10 & 0 & 12 & 13 \\
\hline Benzene & 0 & 0 & 0 & 10 & 10 \\
\hline
\end{tabular}

